\title{
A natural approach to control induced fumonisin B1-histopathological nephrotoxic and hepatotoxic changes in rats
}

\author{
Ashraf A Khali1 ${ }^{*}$, Ashgan Abou Gabal ${ }^{2}$, Amira A Abdellatef ${ }^{3}$, Noha M Zahran ${ }^{4}$, Sahar F Deraz ${ }^{1}$ \\ ${ }^{1}$ Department of Protein Technology, Institute of Genetic Engineering and Biotechnology, City of Scientific Research \& Technological Applications, Bourg \\ Elarab, Alexandria, Egypt. \\ ${ }^{2}$ Faculty of Agriculture (Saba Basha), Alexandria University, Alexandria, Egypt. \\ ${ }^{3}$ City of Scientific Research \& Technological Applications, Bourg Elarab, Alexandria, Egypt. \\ ${ }^{4}$ Department of Histology and Cell Biology, Faculty of Medicine, Alexandria University, Alexandria, Egypt.
}

\begin{tabular}{l}
\hline ARTICLE INFO \\
\hline Received on: 30/11/2017 \\
Accepted on: 09/02/2018 \\
Available online: 07/03/2019 \\
\hline Key words: \\
Histopathology, lipid \\
profile, hepatotoxicity, \\
nephrotoxicity, fumonisins, \\
LAB, detoxification.
\end{tabular}

\begin{abstract}
Among liver and kidney diseases, mycotoxin contamination of feed has become a major concern in animal feed science. A case control study was conducted to evaluate the recovery efficiency of lactic acid bacteria on serum lipid profile parameters and histopathological changes of nephrotoxic and hepatotoxic mycotoxin fumonisin B1 (FB1)induced toxicity in kidney and liver of rats. Eighteen rats were randomly assigned to 12 experimental groups fed various doses of FB1 and/or co-administrated Lactobacillus delbrueckii subsp. lactis DSM 20076 (LL-DSM) and Pediococcus acidilactici NNRL B-5627 (PA-NNRL) for a period of 28 days. After 2 weeks, no significant signs of toxicity in rats fed FB1 alone or co-administrated with LAB were observed. Treatments of LL-DSM and/or PA-NNRL had no effect on organs weight, lipid profile, and histopathological examination of kidney and liver tissues along the experimental period. After 4 weeks, low-density lipoprotein-cholesterol, very low-density lipoprotein-cholesterol, triglycerides and total cholesterol were significantly increased, however the HDL-C, kidney and liver weights were significantly decreased in animals fed FB1 at doses tested. In the same line, the histopathological examination of livers and kidneys showed a series of morphological alterations in animals fed FB1, especially at the high dose (T200). Administration of LAB resulted in a significant improvement in all treatments tested as well as the histopathological patterns of liver and kidney tissues. Thus, using either LL-DSM or PA-NNRL strains could potentially expand another choice for safeguard application against immunotoxicities induced by fumonisins in many farm animal species that face inattentive exposition to this class of mycotoxins in their feedstuff.
\end{abstract}

\section{INTRODUCTION}

With respect to elimination and extraction of both endogenous and exogenous toxin substances, liver is the prime target organ and liver impairment is reflected a critical health issue (Yang et al., 2008). A remarkable feature of the chronic kidney disease (CKD) characterizes both abnormal structure and/or function of kidney (Eknoyan et al., 2013). It had been reported

\footnotetext{
*Corresponding Author

Ashraf A Khalil, Department of Protein Technology, Institute of Genetic Engineering and Biotechnology, City of Scientific Research \& Technological Applications, Alexandria,Egypt.E-mail: Ashraf_khalil@msn.com
}

This article was presented at the 5th Euro-Mediterranean Conference and Expoon Life Sciences, Pharma and Biomedicine (BioNat-V), Limassol, Cyprus. that kidney traumas are initially bounded to the proximal tubules of the outer medulla (also specified as the corticomedullary junction) (Hard et al., 2001) which recognized by disengagement and striping of the apoptotic epithelial cells (little, circle, with pyknotic nuclei) into the lumen (Voss et al., 2007).

On the other hand, for several biological functions, in particular growth and division of both normal and malignant cells, lipids are essential as a main cell membrane component. Lipids are physically related homogeneous group of component and circulatory cholesterol levels modification have been implicated as an etiological agent of colorectal and breast cancer (Forones et al., 1997). Furthermore, the most obvious secondary alterations in lipoprotein metabolism and the extent of changes was found to be correlated to the severity degree of nephrotic syndrome diseases (Mouline et al., 1992). 
In the recent decades, mycotoxin feed contamination along with their results of severe or chronic mycotoxicosis in animals and its relation to liver and kidney diseases has turned into a main subject in animal feed science (Long et al., 2015) which has been reported in grains mainly in maize and its products in animal feeds all over the world (Placinta et al., 1999). Due to their consequence in bringing down animal husbandry efficiency, mycotoxins animal feed contamination have a serious health risk to animals (Williams et al., 2004; Wu and Munkvold, 2008; Zhang and Caupert, 2012). However, in human beings as well as in animals, toxic responses can be induced through a natural mycotoxins exposure route causing mycotoxicoses (Bennett, 1987; Zhang et al., 2015). It had been reported that the primary mycotoxins of concern in the Mediterranean basin and its affected crop are aflatoxins (B1, B2, G1, and G2) in nuts and dried fruits, trichothecenes, and fumonisins in cereals and ochratoxin $\mathrm{A}$ in grapes and raisins (Tsitsigiannis et al., 2012).

The fumonisins are known as the strongest structural similar group of mycotoxins with sphinganine, which is the major precursor of sphingolipids. Fumonisin B1 (FB1) is recognized as the most toxic secondary metabolites and chemically named as 1,2,3-propanetricarboxylic acid, 1,10-[1-(12-amino-4,9,11trihydroxy-2-methyltridecyl)-2-(1-methylpentyl)-1,2-ethanediyl] ester (Marin et al., 2013). In addition to its negative economic impact, fumonisins were identified as potential human carcinogens by the International Agency for Research on Cancer (Sartori et al., 2013). Relevant studies indicated that hepatic and renal toxicity induced by FB1 were predominantly observed in various species (broilers, ducks, turkeys, and rats) and has been statistically correlated with a high incidence of esophageal cancer in human (Ramesh, 2012) as well as its association with nephrotoxicity and liver cancer in rats (Abdel-Wahhab et al., 2002; 2004). The most commonly obtainable information of the main mechanisms of fumonisins toxic action have elucidated an alteration of the cellular lipid metabolism such as increases lipid peroxidation in rat liver and primary rat hepatocytes (Riley et al., 2001). Carryover studies showed that FB1 target organs and toxicity were found to be species- and sex-specific, such as pulmonary edema in pigs, leukoencephalomalacia in horses and in laboratory rodents are hepatotoxic and nephrotoxic. Moreover, FB1 toxicity is targeting the kidney in rats and the liver in mice. While, FB1 renal carcinogenicity is most declared in male rats, whereas in female mice it is liver carcinogenicity (Domijan et al., 2007).

In respect of its human and animal detrimental health effects, serious efforts have been made for either preventing or eliminating mycotoxin all over the world (Aliabadi et al., 2013; Ben Salah-Abbès et al., 2016). Although a number of strategies are available to eradicate mycotoxin contamination, they have many disadvantages due to limited efficacy, practical obstacles, high cost, and possible losses of nutritive value in detoxification process (Shetty and Jespersen, 2006; Sezer et al., 2013).

Many researchers are of the opinion that the most reasonable solution for mycotoxin decontamination should be biological detoxification, giving a possibility for removal of mycotoxins via two main procedures, sorption and enzymatic degradation (Halász et al., 2009; Sezer et al., 2013; Yin et al., 2008). A number of studies have demonstrated that some live or dead microorganisms, especially lactic acid bacteria (LAB), have the ability to either binding the mycotoxin to their cell wall constituents or by active internalization and accumulation. Some relevant studies based on such phenomenon have been utilized in the invention of fluid decontaminated biofilters or probiotics to attach and eliminate mycotoxin from the intestine (Magan and Olsen, 2004). Many studies, both in vivo (animal and human trials) and in vitro (liquid media and cell culture), on the function of probiotic bacteria versus mycotoxins or their deleterious effects, have demonstrated prohibition or renovation of the chronic damage caused by mycotoxins (Vinderola and Ritieni, 2014).

In recent years, many investigators have caught lots of attention of interactions between fungal strains on fumonisin producing Fusarium spp. and antagonists potency of bacteria such as, Azotobacter armeniacus, Burkholderia cepacia, Clonostachys rosea, L. plantarum, L. sanfrancisco, $L$. lactis subsp. lactis, B. subtilis, Bacillus spp., B. mojavensis, $P$. fluorescens, and Trichoderma spp. (Reddy et al., 2010). Stiles and Bullerman (2002) reported the growth prohibition effect and prevention of mycotoxin production of L. rhamnosus on different Fusarium species, including $F$. graminearumm, $F$. proliferatum, and $F$. verticillioides which could inhibit the production of FB1 up to $63.2 \%$, FB2 up to $43.4 \%$, and zearalenone and deoxynivalenol up to $87.5 \%$ and $92 \%$, respectively. Niderkorn et al. (2006) analyzed deoxynivalenol and fumonisin in vitro removal by both lactic and propionic acid bacteria and they pointed out that it was strain specific, with LAB being more efficient than propionic acid bacteria. Up to $55 \%$ of deoxynivalenol was removed by $L$. rhamnosus, while $L$. lactis removed $100 \%$ of FB2, and Leuconostoc mesenteroides removed about $82 \%$ of FB1. A study using Microbacterium oleovorans and B. amyloliquefaciens as seed coatings efficiently reduced both $F$. verticillioides propagules and fumonisin content in maize kernels at harvest (Pereira et al., 2007). Another study demonstrated the fumonisin B1 removal capacity by two strains of L. acidophilus and Saccharomyces cerevisiae. FB1 removal has also been shown to be rapid and reversible, cell viability was not substantial but cell wall structural integrity was required, no chemical alteration of FB1 molecules was involved, and the degree of FB1 elimination was both microorganism and toxin concentration dependent (Pizzolitto et al., 2013).

Based on a previous in vitro study, Lactobacillus delbrueckii subsp. lactis DSM 20076 (LL) and Pediococcus acidilactici NNRL B-5627 (PA) propagated in acidified De Man, Rogosa, Sharpe broth media demonstrated a significant inhibition of Fusarium proliferatum and Fusarium moniliforme extent and reduction in FB1 levels (Khalil et al., 2013). In the present study, the removal of FB1 by LAB and potential beneficial properties were investigated as well as evaluating the histopathological and lipid profile changes in male rats as a part of an ongoing process to establish risk assessment parameters of fumonisins for humans and animals.

\section{MATERIALS AND METHODS}

\section{Chemicals, reagents, and kits}

Standard fumonisin B1 was obtained from Cayman Chemicals Company (Ann Arbor, MI) and a stock solution was 
prepared in acetonitrile/water $(1: 1(\mathrm{v} / \mathrm{v}))$ and kept at $-20^{\circ} \mathrm{C}$ until used. Kits for measuring total-cholesterol (TC), low-density lipoprotein-cholesterol (LDL-C), high-density lipoproteincholesterol (HDL-C), triglyceride (TG), and phospholipids (PL) were purchased from Biodiagnostic (Egypt). All chemicals and solvents used were of analytical grade.

\section{Sources of bacterial and fungal species}

The two bacterial strain used in the current study, $L b$. delbrueckii subsp. lactis DSM 20076 (LL-DSM) and P. acidilactici NNRL B-5627 (PA-NNRL) were obtained from German Collection of Microorganisms and Cell Cultures, Braunschweig, Germany and Northern Regional Research Laboratory (NRRL, Peoria, IL), respectively. The fungal strain (GB accession number: KJ546424) used was F. moniliforme (EMF1), a toxigenic strain previously isolated from a maize with confirmed ability of FB1 toxin production (Khalil et al., 2013).

\section{Experimental animals}

Adult male Sprague-Dawley rats with body weight of $100 \pm 20 \mathrm{~g}$ were received from Faculty of Veterinary, Cairo University, Egypt. Animals were housed in a conditioned atmosphere at temperature of $24 \pm 1^{\circ} \mathrm{C}$ and $55 \pm 5 \%$ relative humidity with regular 12 hours light/12 hours dark cycles and free access to standard laboratory food and water at the animal house of Faculty of Medicine, Alexandria University, Egypt. All experiments have been conducted Under the Regulations and the ethical guidelines for laboratory animals approved by the Ethical Committee of Faculty of Medicine, Alexandria University, Egypt.

\section{Experimental design and diet}

The experiment was conducted using a total of 80 rats divided into 12 groups with 6:7 rats in each. First group (NC) fed on the basal diet and considered as a normal control rats; the second, third and fourth groups (T50, T100, and T200) received the diets contaminated with 50, 100, or $200 \mathrm{mg} \mathrm{FB1/}$ $\mathrm{kg}$ diet, respectively and considered positive controls; the fifth and sixth groups (LL-DSM and PA-NNRL) administrated orally with Lb. delbrueckii subsp. lactis DSM 20076 or P. acidilactici NNRL B-5627 (1010 CFU/mL), respectively and considered negative controls; the seventh and eighth groups (T50-LL and T50-PA) received diets contaminated with $50 \mathrm{mg}$ FB1/ $\mathrm{kg}$ diet and co-administrated with LL-DSM or PA-NNRL, respectively; the 9th and 10th groups (T100-LL and T100-PA) received diets contaminated with $100 \mathrm{mg} \mathrm{FB1} / \mathrm{kg}$ diet and co-administrated with LL-DSM or PA-NNRL, respectively; and finally, the 11th and 12th groups (T200-LL and T200-PA) received diets contaminated with $200 \mathrm{mg} \mathrm{FB1} / \mathrm{kg}$ diet and co-administrated with LL-DSM or PA-NNRL, respectively. Although the duration of the experiment was up to 28-day (4 weeks) post-feeding, organs weight, serum biochemical changes, and histopathological evaluation were studied. Sera were separated using centrifugation under cooling which were then stored at $-20^{\circ} \mathrm{C}$ for the determination of total protein, PL, cholesterol, TGs, HDL-C, LDL-C, and very low density lipoprotein- cholesterol (VLDL-C) according to the kits instructions using Unico UV-2102PC UV/VIS Scanning spectrophotometer (Houston, TX).

\section{Organs weight}

At the end of experimental period (28 days), all rats were were anesthetized by sodium pentobarbital $(4 \%, 40 \mathrm{mg} / \mathrm{kg})$ and sacrificed. From all groups of animals, the liver, kidney, spleen, brain, and testes were removed and weighed.

\section{Blood biochemical parameters}

Blood samples $(2 \mathrm{ml})$ were weekly obtained from retroorbital venous plexus and transferred into dry corked test tubes. Tubes were first held stable at room temperature for 10 minutes, and then centrifuged at 3,000 rpm for 5 minutes. Serum lipid profile was assayed for total cholesterol (TC), TGs, PL, HDL, LDL, and VLDL.

\section{Determination of triglycerides}

Serum samples were analyzed for TGs using the specific assay kit according to the method described by Bucolo and David (1973). The test is based on a series of enzymatic reactions. The method was initiated hydrolysis of TGs through sample incubation glycerol with lipoprotein lipase enzyme. The resulting free glycerol is converted to glycerol-3-phosphate (G3P) and adenosine-5-diphosphate (ADP) by glycerol kinase and ATP. G3P is oxidized by glycerol phosphate dehydrogenase to dihydroxyacetone phosphate and hydrogen peroxide $\left(\mathrm{H}_{2} \mathrm{O}_{2}\right)$. In the last reaction, peroxidase (POD) catalyzes the redox coupled reaction of $\mathrm{H}_{2} \mathrm{O}_{2}$ reacts with 4-aminophenazone (4-AP) and p-chlorophenol to produce red colored dye which was measured spectrophotometrically at $550 \mathrm{~nm}$.

\section{Determination of phospholipids}

PL was estimated as described by Connerty et al. (1961). Nearly, $1 \mathrm{~mL}$ of digestion mixture $(50 \mathrm{ml}$ distilled $\mathrm{H}_{2} \mathrm{O}, 25 \mathrm{ml}$ concentrated sulfuric acid, and $25 \mathrm{ml}$ per-chloric acid, $70 \%$ ) was added to $200 \mu 1$ lipid extract. The mixture was heated in a boiling water bath for about 45 minutes then allowed to cool. Nearly, $1 \mathrm{ml}$ of $50 \%$ sodium acetate was added and completed up to $10 \mathrm{ml}$ with distilled water. The reaction was finalized by adding and $1 \mathrm{ml}$ ammonium molybdate $(2.5 \%)$ followed by $1 \mathrm{ml}$ Elon reagent, then mixed thoroughly together. All tubes were allowed to stand for 15 minutes at room temperature, then absorbance of both test

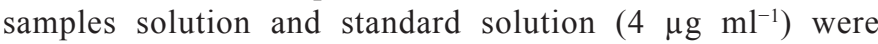
measured at $700 \mathrm{~nm}$ against blank.

\section{Determination of total cholesterol}

Assays of TC in serum were determined by the enzymatic kit method of Richmond (1973) and Allain et al. (1974). The TC colorimetric assay involves three enzymes, cholesterol esterase hydrolyze cholesterol esters to cholesterol and free fatty acids, cholesterol oxidase oxidize free cholesterol to cholest-4-ene-3one and hydrogen peroxide and in presence of POD, the former mixture of 4-aminoantipyrine (4-AA) and ADPS (N-Ethyl-N-(3sulfopropyl)-m-anisidine) are condensed by hydrogen peroxide to form a quinoneimine dye proportional to the concentration of cholesterol in the sample which is quantified by measuring absorbance at $500 \mathrm{~nm}$. 


\section{Determination of HDL-cholesterol}

Serum HDL-C levels were determined by autozyme method using diagnostic kit method described by Burstein and Samaille (1960) which based on the selective separation of HDL-C from other lipoprotein forms by precipitation of apolipoprotein B-containing lipoproteins (primarily VLDL-C and LDL-C) by using phosphotungstic acid/ $\mathrm{MgCl}_{2}$, followed by centrifugation to sediment the precipitant, and subsequent enzymatic analysis of HDL as residual cholesterol remaining in the clear supernatant and color developed was read at $500 \mathrm{~nm}$.

\section{Estimation of LDL- Cholesterol and VLDL-Cholesterol}

LDL-C and VLDL-C levels were calculated via the Friedewald equations (Friedewald et al., 1972).

LDL-Cholesterol $(\mathrm{mg} / \mathrm{dl})=\mathrm{TC}-[(\mathrm{HDL}-\mathrm{C})-1 / 5 \mathrm{TG}]$.

$\mathrm{VLDL}-\mathrm{C}=\mathrm{TGs} / 5$

\section{Liver and kidney histopathological examination}

For the histopathology analyses, liver and kidney tissues from each rat from all the experimental groups were obtained, immediately washed with saline and fixed in a $10 \%$ buffered neutral formalin solution. The fixed tissues samples were dehydrated, embedded in paraffin wax, then, the tissues were sectioned (5-micron thickness) and stained with hematoxylin and eosin (H and E) as described by Lillie et al. (1968). Finally, multiple tissue sections from all groups were examined under a high power microscope at $100 \times, 200 \times$, and $400 \times$ magnifications and photographs using photomicrographic system were obtained.

\section{Statistical analysis}

The data collected were subjected to one-way analysis of variance (ANOVA) to compare organ's weight and blood biochemistry followed by Duncan's multiple range test using a statistical package for the Social Sciences (SPSS) software package version 20. Interaction between times with animal groups using to consider lipid profile. Values of $p \leq 0.05$ were considered as significant.

\section{RESULTS}

\section{Weight changes in selected rat organs}

The chronic effects of FB1-contaminated diets (50, 100 , and $200 \mathrm{mg} \mathrm{FB1} / \mathrm{kg}$ diet) supplemented or not with LAB for 28 days (4 weeks) on selected organs weight were summarized in Table 1. Generally, significant differences were detected in all organs weights among groups after 4 weeks. The data revealed that no significant effects on stomach weight were seen after chronic exposure to different treatments. However, significant differences appeared as of day +28 where the selected organs weight slightly but significantly decreased regardless of the toxin dose observed. Fumonisin B1 at a level of $200 \mathrm{mg} / \mathrm{kg}$ diet was therefore responsible for a statistically significant decrease in the weight of brain, spleen and testes after the ending of exposure. When compared with the control group, the absolute weight of the liver and kidney were lower in FB1 treatments, but not different from the weight reported in treatments with FB1 + $\mathrm{LL}$ and $\mathrm{FB} 1+\mathrm{PA}$. This result suggests that the specification of FB1 in the liver and kidney toxicity. The absolute weight of the kidney fed LL (1.790 g) and PA (1.906 g) was higher $(p \leq 0.05)$ than in the control group (1.565 g). In contrast, no significant changes in the weight of liver, lung, brain, spleen, and testes treated with LL and PA were observed. Feeding FB1 (100, $200 \mathrm{mg} / \mathrm{kg}$ diet) decreased $(p \leq 0.05)$, the absolute weight of the lung by 2.510 and $2.160 \mathrm{~g}$, respectively, compared with $2.983 \mathrm{~g}$ in FB1 treatment $(50 \mathrm{mg} / \mathrm{kg})$. The groups that administered by FB1 + LL and FB1 + PA showed intermediate lung weight (2.945 g). No changes in selected organs weight were observed in animals treated with FB1 + LL and FB1 + PA. These results indicate that the ameliorated effect of $L b$. delbrueckii subsp. lactis DSM 20076 (LL) and P. acidilactici NNRL B-5627 (PA) on Fumonisin B1-toxicosis.

\section{Effect of dietary treatments on serum lipid profile}

Biochemical results of the animal groups revealed that diets containing 50, 100, and $200 \mathrm{mg} \mathrm{FB} / \mathrm{kg}$ increased the serum TG, PL, TC, LDL-C, and VLDL-C (Figs. 1, 2, and 3), compared

Table 1. Changes over time in TGs and PL in serum of treated rats.

\begin{tabular}{|c|c|c|c|c|c|c|}
\hline \multirow{2}{*}{ Groups } & \multicolumn{3}{|c|}{ TG (mg/dl) } & \multicolumn{3}{|c|}{ PL (mg/dl) } \\
\hline & Baseline & Day +14 & Day +28 & Baseline & Day + 14 & Day +28 \\
\hline $\mathrm{NC}$ & $92.7 \pm 6.42^{\mathrm{A}, \mathrm{a}}$ & $95.3 \pm 10.06^{\mathrm{a}}$ & $98.0 \pm 4.00^{\mathrm{a}}$ & $99.83 \pm 15.06^{\mathrm{A}, \mathrm{a}}$ & $130.00 \pm 13.76^{\mathrm{B}, \mathrm{a}}$ & $171.25 \pm 23.54^{\mathrm{E}, \mathrm{b}}$ \\
\hline T50 & $92.0 \pm 8.71^{\mathrm{A}, \mathrm{a}}$ & $96.7 \pm 11.54^{\mathrm{a}, \mathrm{b}}$ & $115.3 \pm 4.16^{b}$ & $103.60 \pm 14.46^{\mathrm{A}, \mathrm{a}}$ & $137.25 \pm 9.21^{\mathrm{B}, \mathrm{a}}$ & $155.66 \pm 5.50^{\mathrm{D}, \mathrm{b}}$ \\
\hline $\mathrm{T} 100$ & $92.7 \pm 4.16^{\mathrm{A}, \mathrm{a}}$ & $108.7 \pm 2.30^{\mathrm{b}}$ & $140.7 \pm 1.15^{\mathrm{c}}$ & $113.50 \pm 14.48^{\mathrm{A}, \mathrm{a}}$ & $134.40 \pm 5.77^{\mathrm{B}, \mathrm{a}}$ & $118.75 \pm 6.29^{\mathrm{C}, \mathrm{a}}$ \\
\hline $\mathrm{T} 200$ & $95.3 \pm 9.018^{\mathrm{A}, \mathrm{a}}$ & $134.0 \pm 2.00^{\mathrm{c}}$ & $164.7 \pm 5.03^{\mathrm{d}}$ & $108.42 \pm 11.57^{\mathrm{A}, \mathrm{a}}$ & $121.83 \pm 4.79^{\mathrm{B}, \mathrm{b}}$ & $96.00 \pm 7.21^{\mathrm{D}, \mathrm{a}}$ \\
\hline LL-DSM & $93.3 \pm 9.01^{\mathrm{A}, \mathrm{a}}$ & $96.7 \pm 6.42^{\mathrm{a}, \mathrm{b}}$ & $94.0 \pm 6.00^{\mathrm{a}}$ & $113.80 \pm 10.20^{\mathrm{A}, \mathrm{a}}$ & $143.00 \pm 9.30^{\mathrm{c}, \mathrm{a}}$ & $194.66 \pm 25.14^{\mathrm{E}, \mathrm{c}}$ \\
\hline PA-NNRL & $92.7 \pm 6.42^{\mathrm{A}, \mathrm{a}}$ & $95.3 \pm 6.11^{\mathrm{a}}$ & $99.3 \pm 12.05^{\text {a }}$ & $101.80 \pm 14.30^{\mathrm{A}, \mathrm{a}}$ & $143.25 \pm 13.12^{\mathrm{C}, \mathrm{a}}$ & $196.00 \pm 13.52^{\mathrm{E}, \mathrm{c}}$ \\
\hline T50-LL & $93.3 \pm 6.42^{\mathrm{A}, \mathrm{a}}$ & $96.0 \pm 5.29^{\mathrm{a}, \mathrm{b}}$ & $98.0 \pm 2.00^{\mathrm{a}}$ & $103.00 \pm 14.76^{\mathrm{A}, \mathrm{a}}$ & $136.40 \pm 9.86^{\mathrm{C}, \mathrm{a}}$ & $162.50 \pm 12.04^{\mathrm{E}, \mathrm{b}}$ \\
\hline T50-PA & $95.3 \pm 6.42^{\mathrm{A}, \mathrm{a}}$ & $97.3 \pm 3.05^{\mathrm{a}, \mathrm{b}}$ & $100.0 \pm 4.0^{\mathrm{a}}$ & $107.60 \pm 14.22^{\mathrm{A}, \mathrm{a}}$ & $136.00 \pm 9.76^{\mathrm{C}, \mathrm{a}}$ & $167.00 \pm 13.11^{\mathrm{E}, \mathrm{b}}$ \\
\hline T100-LL & $92.7 \pm 9.86^{\mathrm{A}, \mathrm{a}}$ & $96.7 \pm 8.32^{\mathrm{a}, \mathrm{b}}$ & $98.0 \pm 7.21^{\mathrm{a}}$ & $105.50 \pm 12.11^{\mathrm{A}, \mathrm{a}}$ & $136.60 \pm 14.92^{\mathrm{C}, \mathrm{a}}$ & $160.00 \pm 8.12^{\mathrm{E}, \mathrm{b}}$ \\
\hline T100-PA & $94.0 \pm 7.21^{\mathrm{A}, \mathrm{a}}$ & $96.7 \pm 5.03^{\mathrm{a}, \mathrm{b}}$ & $98.7 \pm 3.05^{\mathrm{a}}$ & $107.16 \pm 15.79^{\mathrm{A}, \mathrm{a}}$ & $141.00 \pm 9.43^{\mathrm{C}, \mathrm{a}}$ & $168.50 \pm 22.92^{\mathrm{E}, \mathrm{b}}$ \\
\hline T200-LL & $93.3 \pm 7.57^{\mathrm{A}, \mathrm{a}}$ & $96.0 \pm 5.29^{\mathrm{a}, \mathrm{b}}$ & $114.66 \pm 8.71^{b}$ & $100.71 \pm 15.39^{\mathrm{A}, \mathrm{a}}$ & $138.16 \pm 9.82^{\mathrm{C}, \mathrm{a}}$ & $161.20 \pm 17.66^{\mathrm{E}, \mathrm{b}}$ \\
\hline T200-PA & $92.7 \pm 13.31^{\mathrm{A}}$ & $95.3 \pm 7.57^{\mathrm{a}}$ & $112.66 \pm 4.16^{b}$ & $106.28 \pm 15.40^{\mathrm{A}, \mathrm{a}}$ & $136.50 \pm 12.48^{\mathrm{C}, \mathrm{a}}$ & $160.60 \pm 15.53^{\mathrm{E}, \mathrm{b}}$ \\
\hline
\end{tabular}

Each value is mean \pm SD for six rats in each group. Statistical analysis is carried out using one-way ANOVA by SPSS program, V 20.

Means with different letters are significantly different $(p \leq 0.05)$. 
Table 2. Changes over time in TC and HDL-cholesterol in serum of treated rats.

\begin{tabular}{|c|c|c|c|c|c|c|}
\hline \multirow{2}{*}{ Groups } & \multicolumn{3}{|c|}{ Total-Cholesterol (mg/dl) } & \multicolumn{3}{|c|}{ HDL-Cholesterol (mg/dl) } \\
\hline & Baseline & Day +14 & Day +28 & Baseline & Day +14 & Day +28 \\
\hline $\mathrm{NC}$ & $78.0 \pm 7.21^{\mathrm{A}, \mathrm{a}}$ & $80.0 \pm 8.00^{\mathrm{a}}$ & $80.0 \pm 8.00^{\mathrm{a}}$ & $28.32 \pm 4.23^{\mathrm{A}, \mathrm{a}}$ & $27.59 \pm 2.49^{\mathrm{a}}$ & $29.98 \pm 3.17^{\mathrm{a}}$ \\
\hline T50 & $78.7 \pm 011^{\mathrm{A}, \mathrm{a}}$ & $82.7 \pm 4.61^{a}$ & $90.7 \pm 6.11^{b}$ & $27.22 \pm 2.89^{\mathrm{A}, \mathrm{a}}$ & $26.58 \pm 2.97^{\mathrm{a}}$ & $23.83 \pm 4.92^{b}$ \\
\hline $\mathrm{T} 100$ & $78.7 \pm 6.11^{\mathrm{A}, \mathrm{a}}$ & $84.0 \pm 4.00^{\mathrm{a}}$ & $105.3 \pm 5.03^{c}$ & $27.96 \pm 6.49^{\mathrm{A}, \mathrm{a}}$ & $23.47 \pm 6.50^{\mathrm{a}}$ & $19.89 \pm 4.20^{\mathrm{c}}$ \\
\hline $\mathrm{T} 200$ & $78.0 \pm 4.00^{\mathrm{A}, \mathrm{a}}$ & $101.3 \pm 4.16^{b}$ & $130.0 \pm 10.0^{d}$ & $28.96 \pm 8.79^{\mathrm{A}, \mathrm{a}}$ & $21.35 \pm 4.50^{\mathrm{a}}$ & $15.49 \pm 1.58$ \\
\hline LL-DSM & $72.7 \pm 6.11^{\mathrm{A}, \mathrm{a}}$ & $76.0 \pm 4.00^{\mathrm{a}}$ & $75.3 \pm 5.77^{\mathrm{a}}$ & $26.40 \pm 3.99^{\mathrm{A}, \mathrm{a}}$ & $26.95 \pm 3.44^{\mathrm{a}}$ & $26.95 \pm 0.55^{\mathrm{a}}$ \\
\hline PA-NNRL & $74.7 \pm 5.03^{\mathrm{A}, \mathrm{a}}$ & $76.7 \pm 6.42^{\mathrm{a}}$ & $76.7 \pm 4.61^{\mathrm{a}}$ & $27.32 \pm 5.63^{\mathrm{A}, \mathrm{a}}$ & $26.95 \pm 3.44^{\mathrm{a}}$ & $29.15 \pm 5.87^{\mathrm{a}}$ \\
\hline T50-LL & $74.7 \pm 10.26^{\mathrm{A}, \mathrm{a}}$ & $76.7 \pm 8.32^{a}$ & $78.7 \pm 8.08^{a}$ & $28.42 \pm 6.37^{\mathrm{A}, \mathrm{a}}$ & $26.86 \pm 3.09^{a}$ & $28.78 \pm 3.69^{a}$ \\
\hline T50-PA & $76.0 \pm 11.13^{\mathrm{A}, \mathrm{a}}$ & $79.3 \pm 9.01^{\mathrm{a}}$ & $80.7 \pm 8.08^{a}$ & $28.05 \pm 7.21^{\mathrm{A}, \mathrm{a}}$ & $29.24 \pm 7.06^{\mathrm{a}}$ & $27.13 \pm 3.31^{\mathrm{a}}$ \\
\hline T100-LL & $75.3 \pm 8.32^{\mathrm{A}, \mathrm{a}}$ & $78.0 \pm 7.21^{\mathrm{a}}$ & $79.3 \pm 8.08^{a}$ & $26.13 \pm 4.77^{\mathrm{A}, \mathrm{a}}$ & $28.78 \pm 6.33^{\mathrm{a}}$ & $28.97 \pm 6.18^{\mathrm{a}}$ \\
\hline T100-PA & $78.0 \pm 11.13^{\mathrm{A}, \mathrm{a}}$ & $79.3 \pm 9.01^{\mathrm{a}}$ & $80.7 \pm 8.08^{a}$ & $28.23 \pm 9.39^{\mathrm{A}, \mathrm{a}}$ & $28.05 \pm 7.21^{\mathrm{a}}$ & $27.96 \pm 4.71^{a}$ \\
\hline T200-LL & $77.3 \pm 7.02^{\mathrm{A}, \mathrm{a}}$ & $78.7 \pm 4.16^{\mathrm{a}}$ & $88.6 \pm 5.03^{b}$ & $27.76 \pm 4.62^{\mathrm{A}, \mathrm{a}}$ & $29.06 \pm 5.92^{\mathrm{a}}$ & $24.75 \pm 4.35^{b}$ \\
\hline T200-PA & $77.3 \pm 6.42^{\mathrm{A}, \mathrm{a}}$ & $78.0 \pm 5.29^{\mathrm{a}}$ & $90.6 \pm 9.01^{b}$ & $27.68 \pm 7.32^{\mathrm{A}, \mathrm{a}}$ & $29.98 \pm 10.10^{\mathrm{a}}$ & $24.47 \pm 6.33^{b}$ \\
\hline
\end{tabular}

Each value is mean \pm SD for six rats in each group. Statistical analysis is carried out using one-way ANOVA by SPSS program, V 20.

Means with different letters are significantly different $(p \leq 0.05)$.

Table 3. Changes over time in the LDL-cholesterol and VLDL-cholesterol in serum of treated rats.

\begin{tabular}{|c|c|c|c|c|c|c|}
\hline \multirow{2}{*}{ Groups } & \multicolumn{3}{|c|}{ LDL-Cholesterol (mg/dl) } & \multicolumn{3}{|c|}{ VLDL-Cholesterol (mg/dl) } \\
\hline & Baseline & Day + 14 & Day +28 & Baseline & Day + 14 & Day +28 \\
\hline $\mathrm{NC}$ & $31.14 \pm 9.16^{\mathrm{A}, \mathrm{a}}$ & $33.34 \pm 4.96^{\mathrm{a}}$ & $30.43 \pm 7.39^{a}$ & $18.53 \pm 1.28^{\mathrm{A}, \mathrm{a}}$ & $19.07 \pm 2.01^{\mathrm{a}}$ & $19.60 \pm 0.80^{\mathrm{a}}$ \\
\hline T50 & $32.11 \pm 12.38^{\mathrm{A}, \mathrm{a}}$ & $36.38 \pm 8.89^{a}$ & $37.53 \pm 10.44^{b}$ & $18.40 \pm 1.74^{\mathrm{A}, \mathrm{a}}$ & $19.33 \pm 2.30^{\mathrm{a}, \mathrm{b}}$ & $23.07 \pm 0.83^{b}$ \\
\hline $\mathrm{T} 100$ & $32.18 \pm 4.18^{\mathrm{A}, \mathrm{a}}$ & $31.28 \pm 7.25^{\mathrm{a}}$ & $37.78 \pm 1.43^{b}$ & $18.53 \pm 0.83^{\mathrm{A}, \mathrm{a}}$ & $21.73 \pm 0.46^{b}$ & $28.13 \pm 0.23^{\mathrm{c}}$ \\
\hline $\mathrm{T} 200$ & $29.97 \pm 10.95^{\mathrm{A}, \mathrm{a}}$ & $42.63 \pm 6.57^{\mathrm{a}}$ & $62.65 \pm 2.71^{c}$ & $19.07 \pm 1.80^{\mathrm{A}, \mathrm{a}}$ & $26.80 \pm 0.40^{\mathrm{c}}$ & $32.93 \pm 1.00^{d}$ \\
\hline LL-DSM & $27.60 \pm 3.06^{\mathrm{A}, \mathrm{a}}$ & $29.72 \pm 4.71^{\mathrm{a}}$ & $29.58 \pm 6.03^{a}$ & $18.67 \pm 1.80^{\mathrm{A}, \mathrm{a}}$ & $19.33 \pm 1.28^{\mathrm{a}, \mathrm{b}}$ & $18.80 \pm 1.20^{\mathrm{a}}$ \\
\hline PA-NNRL & $28.82 \pm 5.70^{\mathrm{A}, \mathrm{a}}$ & $30.65 \pm 3.73^{a}$ & $27.65 \pm 6.18^{a}$ & $18.53 \pm 1.28^{\mathrm{A}, \mathrm{a}}$ & $19.07 \pm 1.22^{\mathrm{a}}$ & $19.87 \pm 2.41^{\mathrm{a}}$ \\
\hline T50-LL & $27.58 \pm 15.25^{\mathrm{A}, \mathrm{a}}$ & $30.61 \pm 9.28^{a}$ & $30.28 \pm 9.78^{a}$ & $18.67 \pm 1.28^{\mathrm{A}, \mathrm{a}}$ & $19.20 \pm 1.05^{\mathrm{a}, \mathrm{b}}$ & $19.60 \pm 0.40^{\mathrm{a}}$ \\
\hline T50-PA & $28.88 \pm 17.37^{\mathrm{A}, \mathrm{a}}$ & $30.63 \pm 14.73^{a}$ & $33.53 \pm 10.56^{\mathrm{a}}$ & $19.07 \pm 1.28^{\mathrm{A}, \mathrm{a}}$ & $19.47 \pm 0.61^{\mathrm{a}, \mathrm{b}}$ & $20.00 \pm 0.80^{\mathrm{a}}$ \\
\hline T100-LL & $30.68 \pm 5.52^{\mathrm{A}, \mathrm{a}}$ & $29.88 \pm 7.01^{\mathrm{a}}$ & $30.77 \pm 10.50^{\mathrm{a}}$ & $18.53 \pm 1.97^{\mathrm{A}, \mathrm{a}}$ & $19.33 \pm 1.66^{\mathrm{a}, \mathrm{b}}$ & $19.60 \pm 1.44^{\mathrm{a}}$ \\
\hline T100-PA & $30.97 \pm 14.79^{\mathrm{A}, \mathrm{a}}$ & $31.95 \pm 12.33^{\mathrm{a}}$ & $32.98 \pm 9.78^{a}$ & $18.80 \pm 1.44^{\mathrm{A}, \mathrm{a}}$ & $19.33 \pm 1.00^{\mathrm{a}, \mathrm{b}}$ & $19.73 \pm 0.61^{a}$ \\
\hline T200-LL & $30.89 \pm 8.16^{\mathrm{A}, \mathrm{a}}$ & $30.41 \pm 7.57^{\mathrm{a}}$ & $40.98 \pm 9.63^{d}$ & $18.67 \pm 1.51^{\mathrm{A}, \mathrm{a}}$ & $19.20 \pm 1.05^{\mathrm{a}, \mathrm{b}}$ & $22.93 \pm 1.74^{b}$ \\
\hline T200-PA & $31.12 \pm 1.83^{\mathrm{A}, \mathrm{a}}$ & $28.96 \pm 7.74^{\mathrm{a}}$ & $43.65 \pm 5.93^{\mathrm{C}, \mathrm{d}}$ & $18.53 \pm 2.66^{\mathrm{A}, \mathrm{a}}$ & $19.07 \pm 1.51^{\mathrm{a}}$ & $22.53 \pm 0.83^{b}$ \\
\hline
\end{tabular}

Each value is mean \pm SD for six rats in each group. Statistical analysis is carried out using one-way ANOVA by SPSS program, V 20.

Means with different letters are significantly different $(p \leq 0.05)$.

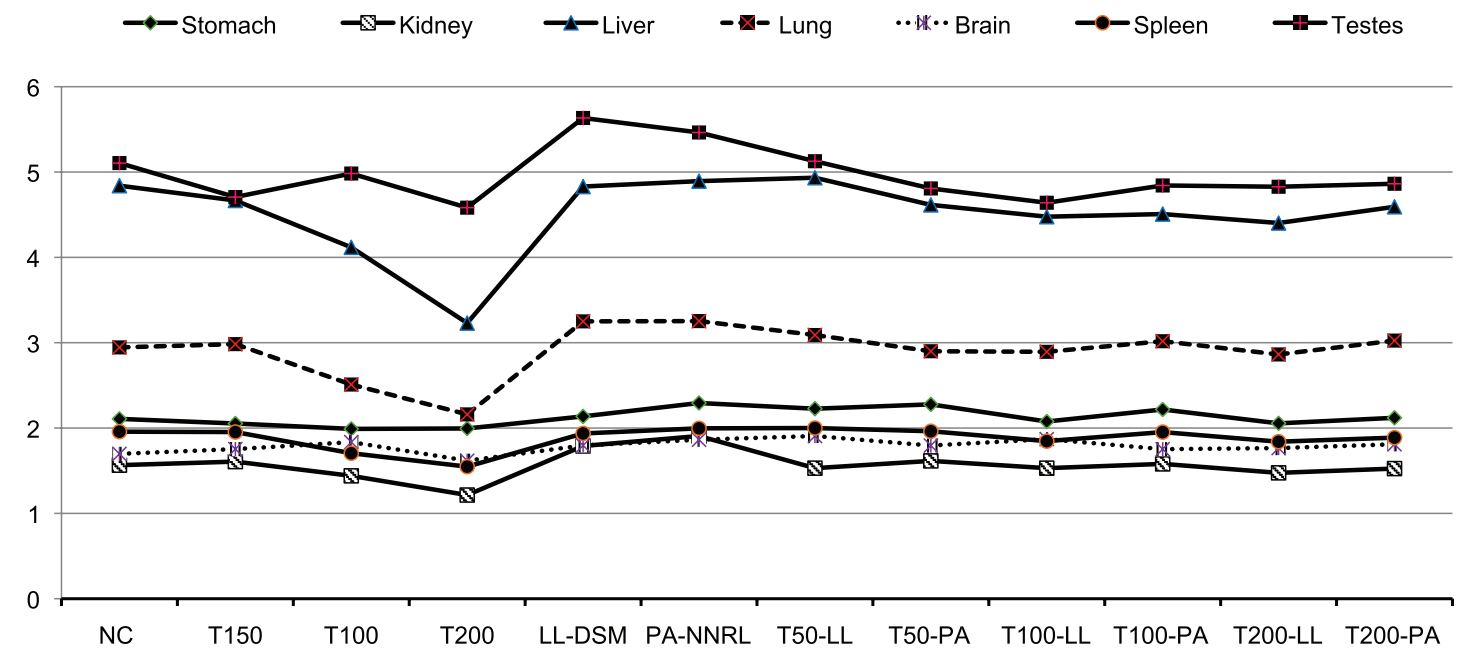

Figure 1. Values of various organ weights $(\mathrm{g})$ of treated male rats over a period of 28 days. 


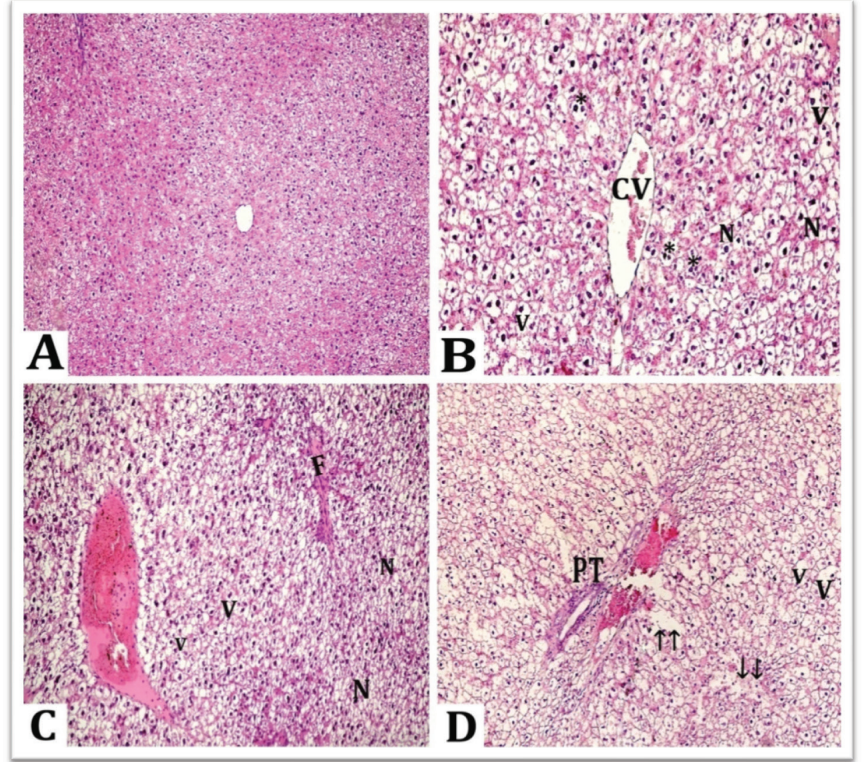

Figure 2. Light photomicrographs of liver sections from: (A) control groups, (B) group treated with low dose of FB1 (T50), and (C and D) Group treated with medium dose of FB1 (T100). (H\&E stain Mic. Magnifications: $100 \times \& 200 \times$ ). V = cytoplasmic vacuolation, ${ }^{*}=$ dilated blood sinusoids, $N=$ pyknosis, $\uparrow \uparrow=e s i n o p h i l i c$ masses, $\mathrm{CV}=$ central vein, $\mathrm{F}=$ fibrosis, and $\mathrm{PT}=$ portal tract.

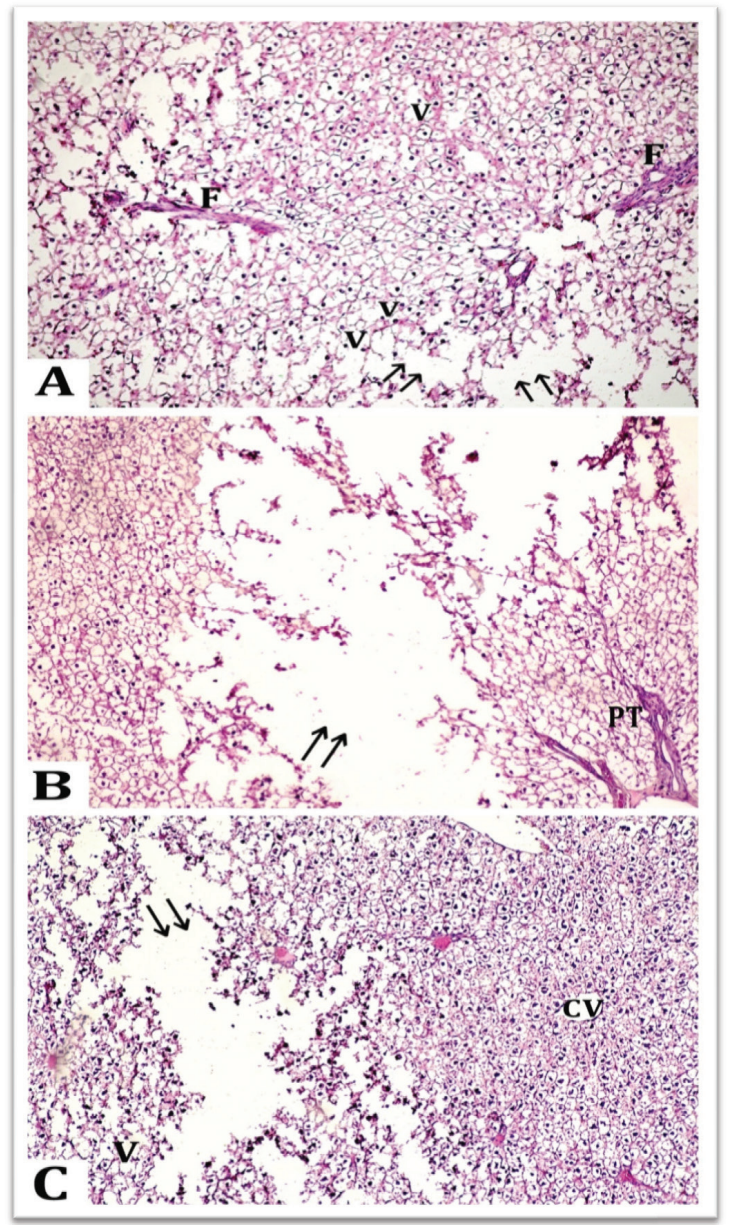

Figure 3. (A, B, and C) Light photomicrographs of liver sections from rats treated with high dose of FB1 (group T200) depicting multiple areas of complete cellular destructions of hepatocytes $(\uparrow \uparrow)$. Congested blood vessels, scattered areas of fibrosis in between portal tract (PT) vacuolated hepatocytes (v) are also seen. (H\&E stain Mic. Magnifications: 200 $\times$ ). V = cytoplasmic vacuolation, ${ }^{*}=$ dilated blood sinusoids, $\uparrow \uparrow=$ esinophilic masses, $\mathrm{CV}=$ central vein, $\mathrm{F}=$ fibrosis, and $\mathrm{PT}=$ portal tract. 
with those fed the control diet while HDL-C (Fig. 3), decreased during the experimental period. The changes in serum lipid profile of growing rats fed dietary FB1 $50 \mathrm{mg} / \mathrm{kg}$ diet (T50-group) are presented, but no significantly changes were reported at the end of the feeding trial. The mean serum cholesterol, LDL-C, and VLDL-C concentrations of the T100-group for day +14 were significantly $(p \leq 0.05)$ lower than the mean serum cholesterol, LDL-C, and VLDL-C of those fed $100 \mathrm{mg} \mathrm{FB1} / \mathrm{kg}$ diet for day +28 , which was significantly $(p \leq 0.05)$ lower than the serum cholesterol, LDL-C, and VLDL-C of those fed on $200 \mathrm{mg} \mathrm{FB1/kg} \operatorname{diet}$ (T200-group) at the end of the feeding trial. The mean serum HDL-C ratio of T100group and T200-group were significantly $(p \leq 0.05)$ lower than the mean serum HDL-C of T50-group and the control diet at about 28 day into the feeding trial. The changes in the serum lipid profile shown in Figures 1, 2, and 3 exhibited time- and dose-dependent of the growing rats. The T200-group significantly increased the mean serum level of TC, LDL-C, VLDL-C, and TG by $62.5 \%$, $105.88 \%, 68.01 \%$, and $68.06 \%$, respectively, compared with control group, while the results showed no great elevation on the serum PL was reported by the end of the experiment. While, the results demonstrated a significantly decrease in the mean serum level of HDL-C by $48.33 \%$, compared with control group.

Along the experimental period, administration of LL or PA only had no effect on the serum TC, HDL-C, LDL-C, VLDL-C, and TG significantly when compared with the control group. In addition, treatments of LL and PA along with FB1 (T50, T100, and T200) induced significant improvements in lipid profile and succeeded to normalize levels of TG, PL, TC, LDL-C, VLDL-C, and HDL-C. Serum TC in T200-LL group and T200-PA group recorded significant reductions of $31.84 \%$ and $30.30 \%$, respectively, while LDL-C significantly reduced by $34.58 \%$ and $30.32 \%$, respectively. VLDL-C significantly reduced by $30.36 \%$ and $31.58 \%$, respectively, and serum TG significantly reduced by $30.38 \%$ and $31.59 \%$, respectively, compared with T200-group. On the other hand, serum level of HDL-C in T200-LL group and T200-PA group recorded a significant elevation by $59.78 \%$ and $57.97 \%$, respectively, compared with T200 group. It was found that the rats treated with Lb. delbrueckii subsp. lactis DSM 20076 (LL) and P. acidilactici NNRL B-5627 (PA) $\left(10^{10} \mathrm{CFU} / \mathrm{ml}\right)$ for 28 days significantly minimized the alterations in the levels of these biochemical parameters.

\section{Histopathological examination of liver tissues}

Microscopic observation of histopathological architecture features of controls liver tissues and the groups treated with LL-DSM or PA-NNRL alone showed normal nucleus of hepatocytes, normal structure of the central vein, radially arranged hepatocytes around the central vein (Fig. 2A). In contrast to the normal histological examination of the liver tissue of the controls, a series of morphological alterations, marked degenerative changes of hepatocytes, congestion, and marked diffuse necrosis of hepatic tissue were observed in liver of FB1-treated rats.

Regarding the liver tissues of T50-group, the data presented dilated central vein (CV) lined by flat endothelial cells. The presences of blood cells in its lumen were noticed. The hepatocytes exhibiting vacuolated cytoplasm (V) with central dense nuclei $(\mathrm{N})$ and some cells are binucleated $(*)$ (Fig. 2B).
These changes were also detected in the liver tissues of T100group in addition to vacuolar degeneration and gross hepatocellular damage. Congested blood vessels scattered the areas of fibrosis in between portal tract (PT) and in between vacuolated hepatocytes (v) were observed in treated tissues, as well. In addition to that, some hepatocytes around portal tract exhibited dense small (pyknotic) nuclei $(\mathrm{N})$, while other cells are completely destructed $(\uparrow \uparrow)$ as shown in Figure $2 \mathrm{C}$ and D. The light photomicrographs of liver sections from T200-group revealed that the liver lost its hepatic architecture and depicted multiple areas of complete cellular destructions of hepatocytes $(\uparrow \uparrow)$. Congested blood vessels scattered the areas of fibrosis in between portal tract (PT) and in between vacuolated hepatocytes (v) were also seen in the same group (Fig. 3A-C).

Further, probiotic bacteria plus FB1 caused a significant decrease in the mean diameter of hepatocytes and central hepatic vein in all treated groups in comparison with FB1 group administration (Fig. 4). The liver of rats treated with FB1 plus LL-DSM (T50-LL) showed acidophilic hepatocytes radiating from normal looking central vein (CV) while other cells appears with vacuolated cytoplasm (V) (Fig. 4A). In addition, light photomicrographs of liver sections from rat group (T50-PA) showed normal looking hepatocytes radiating from central vein (CV) with acidophilic granular cytoplasm and vesicular nuclei $(\mathrm{N})$. The increased phagocytic activity of Kupffer cells $\left(^{\wedge}\right)$ surrounding sinusoids (S) also, noticed in Figure 4B. While, slight degenerative changes or depletion of cells were observed in the rat groups T100-LL and T100-PA. The liver sections in the rat group (T100-LL) showed depicting deposition of collagen fibers around portal tract (PT) and the presence of cellular infiltration (CI). The hepatocytes appeared with vacuolated cytoplasm alternated with areas of granular cytoplasm (Fig. 4C). The rat group T100-PA revealed dilated thin wall central vein (CV) lined by single layer of endothelium. In the same group, the hepatocytes exhibit multiple vacuolated cytoplasms $(\mathrm{V})$ and the nuclei $(\mathrm{N})$ appear dense and centrally located (Fig. 4D). On the other hand, the rat group T200LL showed vacuolated hepatocytes with small dense nuclei $(\mathrm{N})$. Some areas in the same group exhibited fibrosis (F) and focal destruction ( $\uparrow \uparrow$ ) of liver tissue (Fig. 4E). The rat group T200-PA depicted areas of fibrosis $(\mathrm{F})$ in between vacuolated hepatocytes with small dense nuclei (N), as well (Fig. 4F).

\section{Histological examination of kidney tissues}

The histopathological examination of the kidney tissue of the control rats or those treated with probiotic bacteria alone did not reveal any pathological changes, where the renal cortex figured multiple sounded renal glomeruli (g), Bowman's space (S), and proximal convoluted tubules (PCT) appeared with acidophilic cytoplasm, vesicular nuclei $(\uparrow)$ and brush border $(*)$, and the distal convoluted tubules (DCT) with wide lumen (Fig. 5A).

Concerning the FB1 toxicity, the changes in kidney were noticed in rats treated with FB1 (T50-group) after 4 weeks, where the renal glomeruli $(\mathrm{g})$ and renal tubules with focal areas of tubules exhibited vacuolated (V) cytoplasm, while others appeared normal (T) (Fig. 5B). Moreover, rats treated with FB1 (T100-group) exhibited vacuolation of renal tubules cells $(\mathrm{V})$; some tubules have incomplete basal lumen ( $\uparrow$ ) with complete destruction of some cells $(\mathbf{\Lambda})$. In addition, the presence of extra vested blood cells 


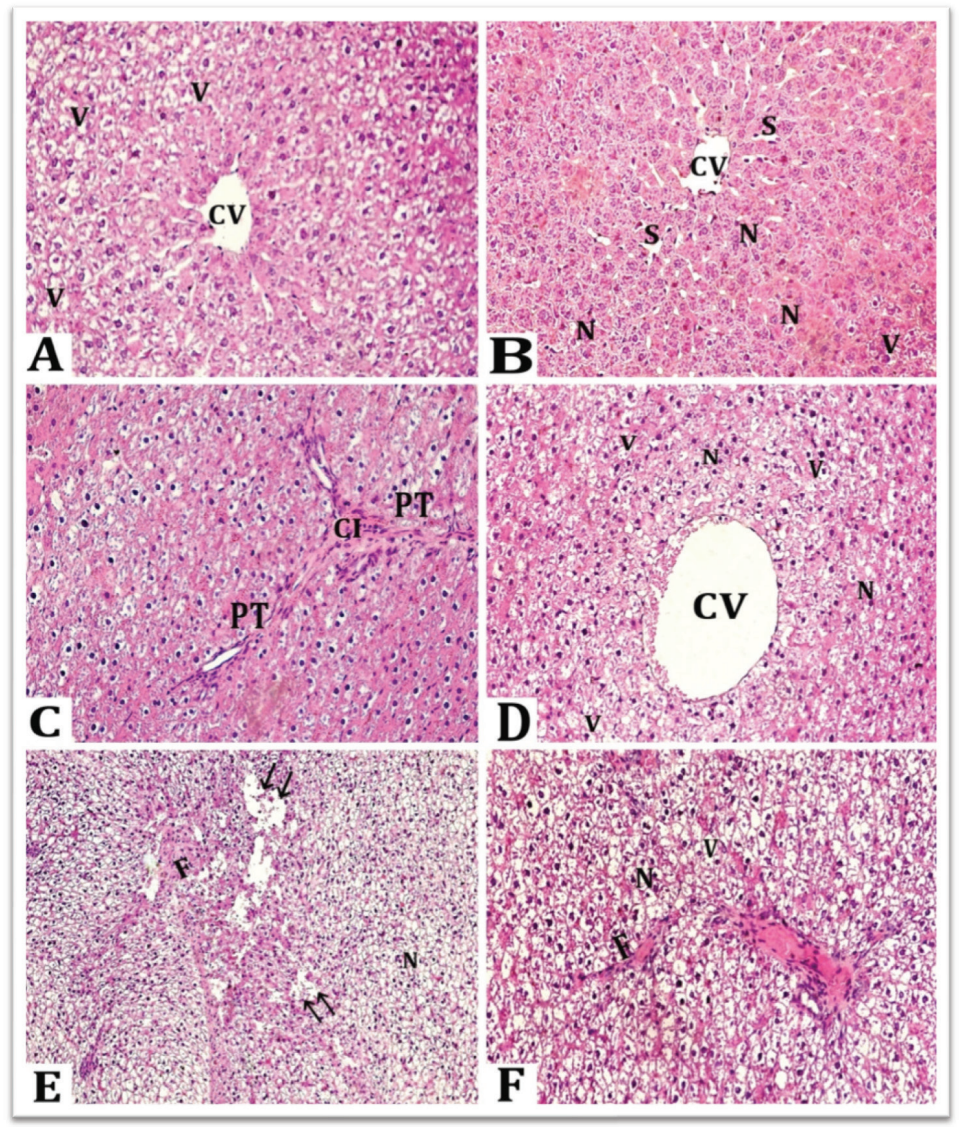

Figure 4. Light photomicrographs of liver sections from: (A) rat group treated with $50 \mathrm{mg}$ FB1/kg diet plus LL (T50-LL); (B) rat group treated with $50 \mathrm{mg}$ FB1/kg diet plus PA (T50-PA); (C) rat group treated with 100mg FB1/kg diet plus LL (T100-LL); (D) rat group treated with 100 mg FB1/kg diet plus PA (T100-PA); (E) rat group treated with $200 \mathrm{mg}$ FB1/kg diet plus LL (T200-LL); and (F) rat group treated with $200 \mathrm{mg}$ FB1/kg diet plus PA (T200-PA) (H\&E stain Mic. Magnifications: $200 \times \& 400 \times) . V=$ cytoplasmic vacuolation, $\mathrm{N}=$ pyknosis, $\uparrow \uparrow=$ esinophilic masses, $\mathrm{CV}=$ central vein, $\mathrm{F}=$ fibrosis, $\mathrm{PT}=$ portal tract, $\mathrm{CI}=$ cellular infiltrate, and $\mathrm{S}=$ Bowman's space.

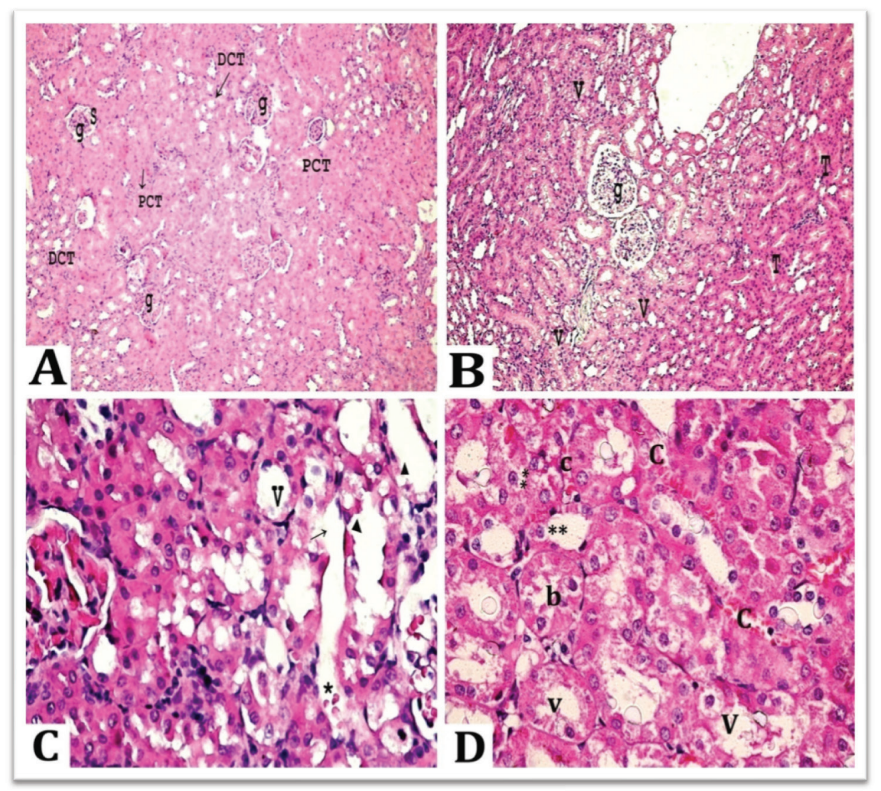

Figure 5. Light photomicrographs of kidney sections from: (A) control groups; (B) rats treated with low dose of FB1 (T50); (C) rats treated with medium dose of FB1 (T100); and (D) rats treated with high dose of FB1 (group T200) (H\&E stain Mic. Magnifications: $100 \times \& 400 \times) . V=$ cytoplasmic vacuolation, $\uparrow=$ vesicular nuclei, $\mathrm{C}=$ congestion, $\mathrm{b}=$ brush border, $\mathrm{S}=$ Bowman's space, $\mathrm{g}=$ Renal glomeruli, $\mathrm{PCT}=$ proximal convoluted tubules, $\mathrm{DCT}=$ distal convoluted tubule, $*=$ dilated blood sinusoids. 


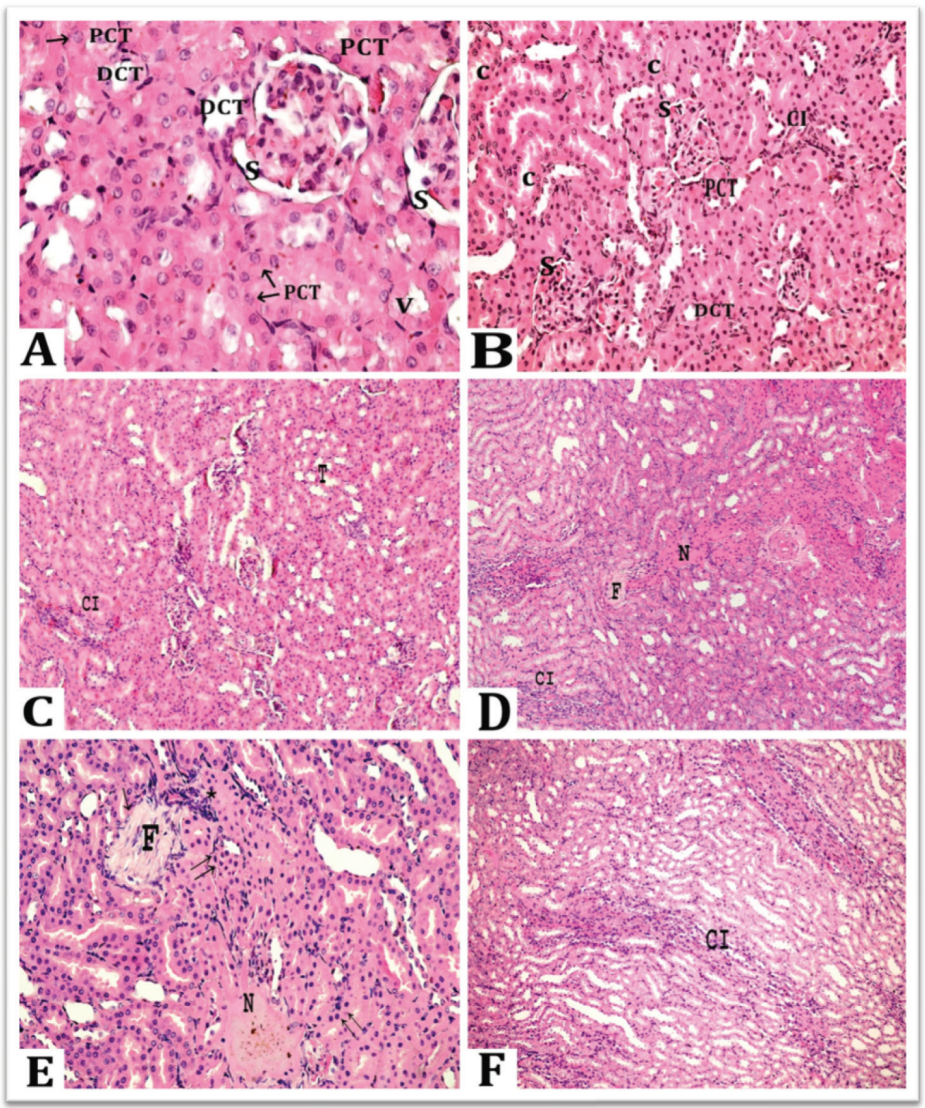

Figure 6. Light photomicrographs of kidney sections from: (A) rat group treated with $50 \mathrm{mg} \mathrm{FB1} / \mathrm{kg}$ diet plus LL (T50-LL); (B) rat group treated with $50 \mathrm{mg}$ FB1/kg diet plus PA (T50-PA); (C) rat group treated with $100 \mathrm{mg}$ FB1/kg diet plus LL (T100-LL); (D) rat group treated with 100 mg FB1/kg diet plus PA (T100-PA); (E) rat group treated with $200 \mathrm{mg} \mathrm{FB1/kg}$ diet plus LL (T200-LL); and (F) rat group treated with $200 \mathrm{mg} \mathrm{FB1/kg}$ diet plus PA (T200-PA) (H\&E stain Mic. Magnifications: $200 \times$ and $400 \times) . \mathrm{V}=$ cytoplasmic vacuolation, $\uparrow=$ vesicular nuclei, $\mathrm{C}=$ congestion, $\mathrm{S}=$ Bowman's space, $\mathrm{g}=$ renal glomeruli, $\mathrm{PCT}=$ proximal convoluted tubules, DCT $=$ distal convoluted tubule, * = dilated blood sinusoids, $\mathrm{F}=$ fibrosis, $\mathrm{CI}=$ cellular infiltrate, $\mathrm{N}=$ necrosis, $\uparrow \uparrow=$ esinophilic masses.

in the lumen of some tubules $(*)$ were also noticed in the same group (Fig. 5C). Histopathology of kidney tissues revealed several changes in rats treated with the high dose of FB1 (T200-group); which observed marked vacuolation (V) of tubular cell lining and some cells appears swollen with central nuclei $(* *)$, with indistinct boundaries. The DCT appeared with diminished brush border (b) and vacuolated cytoplasm. The congestion (C) of blood vessels in between the tubules was seen in this group, as well (Fig. 5D).

On the other hand, the histopathological examinations of the rats showed modifications by the dietary FB1 and LAB supplementation. Where, the kidney of rats treated with FB1 at the low dose plus LL-DSM (T50-LL) showed minor changes in renal glomeruli (g), Bowman's space (S), PCT with acidophilic cytoplasm with minimal vacuolation (V) and rounded vesicular nuclei ( $\uparrow)$, DCT as seen in Figure 6A. The results showed nearly normal structures in the T50-PA group where, the Bowman's space (S) of renal corpuscle decreased, the blood vessels (C) congested, and the structure of PCT and DCT preserved. The minimal cellular infiltrate (CI) also have been noticed (Fig. 6B).

The renal cortex of the rats (T50-LL group) treated with FB1 at the medium level plus LL-DSM showed depiction marked cellular infiltrate (CI), narrow Bowman's space (S), and unaffected renal tubules (T) (Fig. 6C), whereas rats (T50-PA group) supplemented with PA-NNRL observed depicting cellular infiltration (CI) in between tubules of the renal cortex and focal area of cortical necrosis $(\mathrm{N})$ of renal tubules (Fig. 6D).

Light photomicrograph of rat renal cortex in T200-LL group, which treated with high dose of FB1 plus LL-DSM revealed areas of necrosis $(\mathrm{N})$, fibrosis $(\mathrm{F})$, and dark nuclei $(\uparrow \uparrow)$. Cellular infiltrations (CI) are also seen (Fig. 6E) while, T200-PA group supplemented with PA-NNRL showed marked cellular infiltration (CI) in between renal modularly tubules (Fig. 6F). Both livers and kidneys of rats treated with either LL-DSM or PA-NNRL appeared normal and were comparable to those of the control group.

\section{DISCUSSION}

Consumption of fumonisin B1 contaminated foods lead to the induction of nephrotoxicity, hepatotoxicity, carcinogenicity, immunosuppresive, as well as developmental and reproductive toxicity effect in humans and/or animals (Gelderblom et al., 2001; Marasas et al., 2004; Müller et al., 2012; NTP, 2001; Riley et al., 1994; Voss et al., 1995).

To control FB1-induced damages, different strategies have been developed to detoxify fumonisin B1 contaminated foods and animal feeds. The targets of these strategies are including detoxification of the already present mycotoxins, banning of 
FB1 gastrointestinal tract absorption, damage reduction when absorption occurs. Recently, increasing interest has been raised on the hypothesis that some dairy strains of LAB and bifidobacteria can effectively inhibit mycotoxin absorption in consumed food which later on proofed by numerous investigators (El-Nezami et al., 1998; Kankaanpää et al., 2000; Oatley et al., 2000). The ability of Lb. delbrueckii subsp. lactis DSM 20076 and $P$. acidilactici NNRL B-5627 to inhibit Fusarium sp. isolates growth and/or bind fumonisin were studied in vitro by Khalil et al. (2013); in which we reported removal of high amounts $(76.67 \%)$ of FB1 by Lb. delbrueckii subsp. lactis DSM 20076. However, P. acidilactici NNRL B-5627 showed the greatest inhibitory effect against Fusarium isolates suggesting that these strains would be useful for dietary detoxification. Furthermore, Khalil et al. (2015) reported a good protective effect as antigenotoxicity and precancerous lesions of both $L b$. delbrueckii subsp. lactis (LL) and $P$. acidilactici (PA) strains.

In the current research, an in vivo study was conducted to evaluate the ameliorating efficiency of LL and PA strains against FB1-induced toxicity in in rats. Serum lipid profile parameters (TG, PL, TC, LDL-C, VLDL-C, and HDL-C) were determined along with the nephrotoxic and hepatotoxic changes. Rates fed FB1-contaminated diets tended to have a decrease in organs weights with pronounced reductions in absolute weight of livers and kidneys; in a similar trend to previous findings reported by other researchers (Howard et al., 2001; Sharma et al., 1997; Tsunoda et al., 1998). In contrast, no significant changes observed in absolute weights of livers, lungs, brains, spleens, and testes in LL- and PA-treated rates. These results confirmed former literature data, where the toxic effects were counteracted by LAB (Gratz et al., 2006; Nada et al., 2010).

In addition, administration of LL and PA to rats fed FB1 (groups T50, T100, and T200) induced significant improvements in lipid profile and succeeded to normalize values of TG, PL, TC, LDL-C, VLDL-C, and HDL-C. However, the significant increment of LDL + VLDL cholesterol, TG, and TC in animals fed FB1 at various doses tested may refer to ceramide synthase inhibition caused by FB1 which leads to a wide spectrum of changes in lipid metabolism and associated lipid-dependent signaling pathways (Merrill et al., 2001). Studies have suggested that the lipid metabolism impairment of liver tissues by mycotoxin as the major cause to the changes in the serum cholesterol and TGs (Juma et al., 2015). In agreement with other former studies, we detected mild to moderate apoptotic, mitotic, and other effects consistent with fumonisin exposure in all rats fed FB1 with differences in severity in relation to $\mathrm{FB} 1$ dose.

Histopathological structure abnormalities of both kidney and liver tissues were similar to those seen in other reports (Bondy et al., 1996; 1998; Bulder et al., 2012; El-Nekeety et al., 2007; Gelderblom et al., 1994; 1996; Voss et al., 2001). The histological results reported in the current study confirmed the biochemical results previously obtained (Khalil et al., 2015), in which the experimental animal fed FB1-contaminated corn affected both liver and kidney functions markers as differentiated by increased serum levels of AST, ALT, ALP, urea, and creatinine. However, co-administration of $L b$. delbrueckii subsp. lactis (LL) and $P$. acidilactici (PA) significantly reduced serum hepatic biomarkers and serum parameters of kidney functions to the normal levels.
Because of the similarity between fumonisins and the sphingoid bases sphinganine (Sa) and sphingosine (So), a close correlation was observed between disruption of sphingolipid metabolism caused by FB1 exposure and tissue lesions detectable by light microscopy consisted of at least one of the following structures: fibrosis, bile duct proliferation, single cell necrosis, pyknosis, hepatocellular cytoplasmic vacuolation, variation in staining properties and nuclear size, mild to noticed hepatocellular hyperplasia and more severely affected livers showed mitotic figures, and foci of cellular alteration (Abdel-Wahhab et al., 2004; El-Nekeety et al., 2007; Karabela et al., 2011). Sphingolipids are a highly diverse class of lipids with diverse biological in signaling pathways responsible for cell growth, differentiation and death (Merrill et al., 1997). Furthermore, altered proliferation and altered morphology along with abnormal behavior of fumonisin-treated cells is correlated to depletion of more complex sphingolipids (Merrill et al., 2001; Riley et al., 2001; WHO, 2000; 2002), and this has been set as proposed mechanism for nephrotoxicity induced in male rats exposed FB1 through the disruption of cell-cell interactions (Hard et al., 2001). LL and PA strains were abled to mitigate, counteract, and/or reverse the effects of FB1, regardless the dose and timing. The protective effects of LL and PA could be explained by the ability of these bacteria to bind FB1 in vitro or in the gastrointestinal tract and, thereby, reduce its bioavailability (Khalil et al., 2013; 2015). The first hypothesis for explaining mechanisms revealed that Grampositive strains mainly LAB and bifidobacteria were more efficient than Gram-negative strains to bind mycotoxin suggesting that the two most important elements responsible for the binding and the absorption of mutagens and carcinogens in small intestine are the cell wall peptidoglicans and polysaccharides (El-Nezami et al., 2000; Haskard et al., 2000). Past and recent researches considered that binding is a main mechanism of detoxification by LAB (Gratz, 2007; Niderkorn et al., 2009; Zoghi et al., 2014). However, for a better understanding of the precise in vivo binding mechanisms, further systematic studies are still required. In vivo study in rats using L. rhamnosus GG and L. casei Shirota showed ameliorated hepatic damage induced by FB1 through activity enhancement of antioxidant enzymes (Kumar et al., 2012). Another study suggested that lipid peroxidation reduction in liver and kidney by $L$. casei and $L$. reuteri led to modulation of the oxidative stress in rats fed aflatoxin-contaminated diet (Hathout et al., 2011).

Another detoxification proposed mechanism has been postulated that LAB exerts its effects through their capability to metabolize FB1 (Fodor et al., 2007) which based on some other former studies. The eviction path of FB1 is through bile and the secreted toxin is still biologically active (Enongene et al., 2000). Traces quantities of fully hydrolyzed FB1 (aminopentol) were detected in feces (Shephard et al., 1994). However, no hydrolyzed product has been detected either in the urine or bile. Therefore, it is presumed that the hydrolysis happens in the gut and most likely performed by microorganisms (Fodor et al., 2006; Shephard et al., 1995). In a recent study by Dang et al. (2017), hydrolyzed FB1 was found after 24 hours incubation and the concentration was doubled after 48 hours incubation in the presence of Lactobacillus sp., Bacteroides, and Prevotella and the number of studied bacteria did not negatively affected. These results pointed out that the FB1 can be metabolized by gut microbiota. 


\section{CONCLUSION}

Lactobacillus delbrueckii subsp. lactis DSM 20076 (LL-DSM) and $P$. acidilactici NNRL B-5627 (PA-NNRL), a selected $\mathrm{LAB}$ with pronounced FB1-binding ability in vitro, normalizing serum levels of AST, ALT, ALP, urea, and creatinine and reduction of the DNA damage in FB1-intoxicated rats. In the current study, those strains could also induce a significant improvement in lipid profile and succeeded to normalize TG, PL, TC, LDL-C, VLDL-C, and HDL-C with significant minimization of the alterations in the levels of these biochemical parameters. Furthermore, the histopathological examinations of both liver and kidney of rats fed FB1 and co-administrated with either LL-DSM or PA-NNRL appeared normal and was comparable to those of the control group. Thus, use of either LL-DSM or PA-NNRL strains could potentially expand another choice for safeguard application against immunotoxicities induced by fumonisins in many farm animal species that face inattentive exposition to this class of mycotoxins in their feedstuff.

\section{ACKNOWLEDGMENTS}

The authors appreciate the technical support by the laboratory staff at the Department of Histology and Cell Biology, Faculty of Medicine, Alexandria University, Alexandria, Egypt.

\section{ROLE OF FUNDING SOURCE}

This work was supported by City of Scientific Research and Technological Application.

\section{CONFLICT OF INTEREST}

There are no conflicts of interest.

\section{REFERENCES}

Abdel-Wahhab M, Amer H, Hassan N, Hassan A, Naguib K. Effects of garlic and cabbage extracts on fuminisin-induced toxicity in rats. J Egypt Soc Toxicol, 2002; 26:1-12.

Abdel-Wahhab MA, Hassan AM, Amer HA, Naguib KM. Prevention of fumonisin-induced maternal and developmental toxicity in rats by certain plant extracts. J App Toxicol, 2004; 24:469-74.

Aliabadi MA, Alikhani FE, Mohammadi M, Darsanaki RK. Biological control of aflatoxins. Eur J Exp Biol, 2013; 3:162-6.

Allain CC, Poon LS, Chan CS, Richmond W, Fu PC. Enzymatic determination of total serum cholesterol. Clin Chem, 1974; 20:470-5.

Ben Salah-Abbès J, Jebali R, Sharafi H, Noghabi KA, Oueslati R, Abbès S. Immuno-physiological alterations from AFB1 in rats counteracted by treatments with Lactobacillus paracasei BEJ01 and montmorillonite clay mixture. J Immunotoxicol, 2016; 13:628-37.

Bennett J. Mycotoxins, mycotoxicoses, mycotoxicology and mycopathologia. Mycopathologia, 1987; 100:3-5.

Bondy G, Barker M, Mueller R, Fernie S, Miller JD, Armstrong C, Hierlihy SL, Rowsell P, Suzuki C. Fumonisins B1 toxicity in male Sprague-Dawley rats. In: Jackson LS, De Vries JW, Bullerman LB (eds.). Fumonisins in food (advances in experimental medicine and biology). Plenum Press, New York, pp 251-64,

Bondy GS, Suzuki CAM, Mueller RW, Fernie SM, Armstrong CL, Hierlihy SL, Savard ME, Barker MG. Gavage administration of the fungal toxin fumonisin B1 to female Sprague-Dawley rats. J Toxicol Environ Health, 1998; 53:135-51.

Bucolo G, David H. Quantitative determination of serum TGs by the use of enzymes. Clin Chem, 1973; 19:476-82.

Bulder AS, Arcella D, Bolger M, Carrington C, Kpodo K, Resnik S, Riley RT, Wolterink G, Wu F. Fumonisins (addendum). In: World Health
Organization (ed.). Safety evaluation of certain food additives and contaminants, WHO Food Additives Series 65, WHO, Geneva, pp 325-794, 2012.

Burstein M, Samaille J. On a rapid determination of the cholesterol bound to the serum alpha-and beta-lipoproteins. Clin Chim Acta, 1960; 5:609 (in French).

Connerty HV, Briggs AR, Eaton Jr EH. Determination of serum, phospholipids, lipid phosphorous. In: Varley $\mathrm{H}$ (ed.). Practical clinical biochemistry, CBS Publishers, India, pp 319-20, 1961.

Dang HA, Zsolnai A, Kovacs M, Bors I, Bonal A, Bota B, Szabo-Fodor J. In vitro interaction between fumonisin B1 and the intestinal microflora of pigs. Pol J Microbiol, 2017; 66, 245-50.

Domijan AM, Peraica M, Vrdoljak AL, Radić B, Žlender V, Fuchs R. The involvement of oxidative stress in ochratoxin A and fumonisin B1 toxicity in rats. Mol Nutr Food Res, 2007; 51:1147-51.

Eknoyan G, Lameire N, Eckardt K, Kasiske B, Wheeler D, Levin A, Stevens P, Bilous R, Lamb E, Coresh J. Kidney disease: improving global outcomes (KDIGO) CKD work group. KDIGO 2012 clinical practice guideline for the evaluation and management of chronic kidney disease. Kidney Int, 2013; 3:5-14.

El-Nekeety AA, El-Kholy W, Abbas NF, Ebaid A, Amra HA, AbdelWahhab MA. Efficacy of royal jelly against the oxidative stress of fumonisin in rats. Toxicon, 2007; 50:256-69.

El-Nezami H, Kankaanpää P, Salminen S, Ahokas J. Ability of dairy strains of lactic acid bacteria to bind a common food carcinogen, aflatoxin B1. Food Chem Toxicol, 1998; 36:321-6.

El-Nezami H, Mykkanen H, Kankaanpaa P, Suomalainen T, Salminen S, Ahokas J. Ability of a mixture of Lactobacillus and Propionibacterium to influence the faecal aflatoxin content in healthy Egyptian volunteers: a pilot clinical study. Bioscience Microflora, 2000; 19:41-5.Enongene EN, Sharma RP, Bhandari N, Voss KA, Riley RT. Disruption of sphingolipid metabolism in small intestines, liver and kidney of mice dosed subcutaneously with fumonisin B1. Food Chem Toxicol, 2000; 38:793-9.

Fodor J, Meyer K, Gottschalk C, Mamet R, Kametler L, Bauer J, Horn P, Kovács F, Kovács M. In vitro microbial metabolism of fumonisin B1. Food Addit Contam, 2007; 24:416-20.

Fodor J, Meyer K, Riedlberger M, Bauer J, Pósa R, Horn P, Kovács F, Kovács M. Distribution and elimination of fumonisin analogues in weaned piglets after oral administration of Fusarium verticillioides fungal culture. Food Addit Contam, 2006; 23:492-501.

Forones N, Falcao J, Mattos D, Barone B. Cholesterolemia in colorectal cancer. Hepato-gastroenterol, 1997; 45:1531-4.

Friedewald WT, Levy RI, Fredrickson DS. Estimation of the concentration of low-density lipoprotein cholesterol in plasma, without use of the preparative ultracentrifuge. Clin Chem, 1972; 18:499-502.

Gelderblom WC, Abel S, Smuts CM, Marnewick J, Marasas WF, Lemmer ER, Ramljak D. Fumonisin-induced hepatocarcinogenesis: mechanisms related to cancer initiation and promotion. Environ Health Perspect, 2001; 109:291-300.

Gelderblom WCA, Cawood ME, Snyman SD, Marasas WFO. Fumonisin B1 dosimetry in relation to cancer initiation in rat liver Carcinogenesis, 1994; 15:209-14.

Gelderblom WCA, Snyman SD, Lebepe-Mazur S, van der Westhuizen L, Kriek NPJ, Marasas WFO. The cancer-promoting potential of fumonisin B1 in rat liver using diethylnitrosamine as a cancer initiator. Cancer Lett, 1996; 109:101-8.

Gratz S. Aflatoxin binding by probiotics. Experimental studies on intestinal aflatoxin transport, metabolism and toxicity. $\mathrm{PhD}$ Thesis, University of Kuopio, Finland, 2007.

Gratz S, Täubel M, Juvonen R, Viluksela M, Turner P, Mykkänen H, ElNezami H. Lactobacillus rhamnosus strain GG modulates intestinal absorption, fecal excretion, and toxicity of aflatoxin B1 in rats. App Environ Microbiol, 2006; 72:7398-400.

Halász A, Lásztity R, Abonyi T, Bata Á. Decontamination of mycotoxin-containing food and feed by biodegradation. Food Rev Int $2009 ; 25: 284-98$. 
Hard GC, Howard PC, Kovatch RM, Bucci TJ. Rat kidney pathology induced by chronic exposure to fumonisin B1 includes rare variants of renal tubule tumor. Toxicologic pathol, 2001; 29:379-86.

Haskard C, Binnion C, Ahokas J. Factors affecting the sequestration of aflatoxin by Lactobacillus rhamnosus strain GG. Chem Biol Interact, 2000; 128:39-49.

Hathout AS, Mohamed SR, El-Nekeety AA, Hassan NS, Aly SE, Abdel-Wahhab MA. Ability of Lactobacillus casei and Lactobacillus reuteri to protect against oxidative stress in rats fed aflatoxins-contaminated diet. Toxicon, 2011; 58:179-86.

Howard PC, Warbritton A, Voss KA, Lorentzen RJ, Thurman JD, Kovach RM, Bucci TJ. Compensatory regeneration as a mechanism for renal tubule carcinogenesis of fumonisin B1 in the F344/N/Nctr BR rat. Environ Health Perspect, 2001; 109:309-14.

Juma KK, Fulakeza RMJ, Ngeranwa JN, Ngugi MP, Mburu ND. Evidence based phytopharmacological potential of herbal extracts in postingestion management of mycotoxins in animal models. J Clin Toxicol, $2015 ; 5: 260-8$.

Kankaanpää P, Tuomala E, El-Nezami H, Ahokas J, Salminen SJ. Binding of aflatoxin B1 alters the adhesion properties of Lactobacillus rhamnosus strain GG in a Caco-2 model. J Food Prot, 2000; 63:412-4.

Karabela SP, Kairi CA, Magkouta S, Psallidas I, Moschos C, Stathopoulos I, Zakynthinos SG, Roussos C, Kalomenidis I, Stathopoulos GT. Neutralization of tumor necrosis factor bioactivity ameliorates urethaneinduced pulmonary oncogenesis in mice. Neoplasia, 2011; 13:1143-51.

Khalil AA, Abou-Gabal AE, Abdellatef AA, Khalid AE. Protective role of probiotic lactic acid bacteria against dietary fumonisin B1-induced toxicity and DNA-fragmentation in sprague-dawley rats. Prep Biochem Biotechnol, 2015; 45:530-50.

Khalil AA, Abou-Gabal AE, Elfaramawy AM, Khaled AE, Abdellatef AA. Lactic acid bacteria as antimycotic and antimycotoxins agents against toxigenic Fusarium species Associated to maize grains stored in Egyptian markets. J Pure App Microbiol, 2013; 7:93-105.

Kumar M, Verma V, Nagpal R, Kumar A, Behare PV, Singh B, Aggarwal PK. Anticarcinogenic effect of probiotic fermented milk and chlorophyllin on aflatoxin-B1-induced liver carcinogenesis in rats. $\mathrm{Br} \mathrm{J}$ Nutr, 2012; 107:1006-16.

Lillie R, Pasternack J, Gabe M. Techniques histologiques. Masson et Cie, Paris, p 249, 1968.

Long XD, Huang HD, Huang XY, Yao JG, Xia Q. XPC codon 939 poly-morphism is associated with susceptibility to DNA damage induced by AFB1 exposure. Int J Clin Exp Med, 2015; 8:1197-204.

Magan N, Olsen M. Mycotoxins in food: detection and control. Woodhead Publishing Limited, Sawston, UK, 2004.

Marasas WF, Riley RT, Hendricks KA, Stevens VL, Sadler TW, Gelineau-van Waes J, Missmer SA, Cabrera J, Torres O, Gelderblom WC, Allegood J, Martinez C, Maddox J, Miller JD, Starr L, Sullards MC, Roman AV, Voss KA, Wang E, Merrill Jr AH. Fumonisins disrupt sphingolipid metabolism, folate transport, and neural tube development in embryo culture and in vivo: a potential risk factor for human neural tube defects among populations consuming fumonisin-contaminated maize. J Nutr, 2004; 134:711-6.

Marin S, Ramos A, Cano-Sancho G, Sanchis V. Mycotoxins: occurrence, toxicology, and exposure assessment. Food Chem Toxicol, $2013 ; 60: 218-37$

Merrill AH, Jr Schmelz EM, Dillehay DL, Spiegel S, Shayman JA, Schroeder JJ, Riley RT, Voss KA, Wang E. Sphingolipids - the enigmatic lipid class: biochemistry, physiology, and pathophysiology. Toxicol Appl Pharmacol, 1997; 42:208-25.

Merrill AH, Jr Sullards MC, Wang E, Voss KA, Riley RT. Sphingolipid metabolism: roles in signal transduction and disruption by fumonisins. Environ Health Perspect, 2001; 109:283-9.

Mouline B, Ollier S, Olmer M. Disturbances of lipid metabolism during nephrotic syndrome. Nephrol, 1992; 13:193-9.

Müller S, Dekant W, Mally A. Fumonisin B1 and the kidney: modes of action for renal tumor formation by fumonisin B1 in rodents. Food Chem Toxicol, 2012; 50:3833-46.
Nada S, Amra H, Deabes M, Omara E. Saccharomyces Cerevisiae and probiotic bacteria potentially inhibit aflatoxins production in vitro and in vivo studies. Int J Toxicol, 2010; 8:32.

Niderkorn V, Boudra H, Morgavi D. Binding of Fusarium mycotoxins by fermentative bacteria in vitro. J App Microbiol, 2006; 101:849-56.

Niderkorn V, Morgavi DP, Aboab B, Lemaire M, Boudra H Cell wall component and mycotoxin moieties involved in the binding of fumonisin B1 and B2 by lactic acid bacteria. J Appl Microbiol, 2009; 106:977-85.

NTP. Toxicology and carcinogenesis studies of fumonisin B1 (CAS No. 116355-83-0) in F344/N rats and B6C3F1 mice (Feed Studies). Natl Toxicol Program Tech Rep Ser, 2001; 496:1-352.

Oatley JT, Rarick MD, Ji GE, Linz JE. Binding of aflatoxin B1 to Bifidobacteria in vitro. J Food Prot, 2000; 63:1133-6.

Pereira P, Nesci A, Etcheverry M. Effects of biocontrol agents on Fusarium verticillioides count and fumonisin content in the maize agroecosystem: impact on rhizospheric bacterial and fungal groups. Biol control, 2007; 42:281-7.

Pizzolitto R, Armando M, Salvano M, Dalcero A, Rosa C. Evaluation of Saccharomyces cerevisiae as an antiaflatoxicogenic agent in broiler feedstuffs. Poult sci, 2013; 92:1655-63.

Placinta C, D'mello J, Macdonald AA. Review of worldwide contamination of cereal grains and animal feed with Fusarium mycotoxins. Anim feed sci technol, 1999; 78:21-37.

Ramesh G. Symptoms, diagnosis, and pathophysiology of mycotoxin exposure. Murray State University, Hopkinsville, Kentucky, 2012.

Reddy K, Farhana N, Salleh B, Oliveira C. Microbiological control of mycotoxins: present status and future concerns. Cur Res Technol Edu Topics App Microbiol Microbial Biotechnol, 2010; 2:1078-86.

Richmond W. Preparation and properties of a cholesterol oxidase from Nocardia sp. and its application to the enzymatic assay of total cholesterol in serum. Clin Chem, 1973; 19:1350-6.

Riley RT, Enongene E, Voss KA, Norred WP, Meredith FI, Sharma RP, Spitsbergen J, Williams DE, Carlson DB, Merrill Jr AH. Sphingolipid perturbations as mechanisms for fumonisin carcinogenesis. Environ Health Perspect, 2001; 109:301-8.

Riley RT, Hinton DM, Chamberlain WJ, Bacon CW, Wang $\mathrm{E}$, Merrill Jr AH, Voss KA. Dietary fumonisin B1 induces disruption of sphingolipid metabolism in Sprague-Dawley rats: a new mechanism of nephrotoxicity. J Nutr, 1994; 124:594-603.

Sartori M, Nesci A, Castillo C, Etcheverry M. Biological control of fumonisins production in maize at field level. Int J Agric Policy Res, $2013 ; 1: 188-96$.

Sezer C, Guven A, Bilge Oral N, Vatansever L. Detoxification of aflatoxin $\mathrm{B} 1$ by bacteriocins and bacteriocinogenic lactic acid bacteria. Turk J Vet Anim Sci, 2013; 37:594-601.

Sharma RP, Dugyala RR, Voss KA. Demonstration of in-situ apoptosis in mouse liver and kidney after short-term repeated exposure to fumonisin B1. J comp Pathol, 1997; 117:371-81.

Shephard GS, Thiel PG, Sydenham EW, Savard ME. Fate of a single dose of $14 \mathrm{C}$ labelled fumonisin B1 in vervet monkeys. Nat Toxins, $1995 ; 3: 145-50$.

Shephard GS, Thiel PG, Sydenham EW, Vleggaar R, Alberts JF. Determination of the mycotoxin fumonisin B1 and identification of its partially hydrolysed metabolites in the faeces of non-human primates. Food Chem Toxicol, 1994; 32:23-9.

Shetty PH, Jespersen L. Saccharomyces cerevisiae and lactic acid bacteria as potential mycotoxin decontaminating agents. Trends Food Sci Technol, 2006; 17:48-55.

Stiles J, Bullerman L. Inhibition of Fusarium species and mycotoxin production by Bacillus pumilus NEB1 and Lactobacillus rhamnosus VT1. 13th International Reinhardsbrunn Symposium, Modern Fungicides and Antifungal Compounds III Agro Concept GmbH, Germany, 2002.

Tsitsigiannis DI, Dimakopoulou M, Antoniou PP, Tjamos EC. Biological control strategies of mycotoxigenic fungi and associated mycotoxins in Mediterranean basin crops. Phytopathol Mediterr, 2012; $51: 158-74$. 
Tsunoda M, Shanna RP, Riley RT. Early fumonisin B1, toxicity in relation to disrupted sphingolipid metabolism in male BALB/c mice. J Biochem Mol Toxicol, 1998; 12:281-9.

Vinderola G, Ritieni A. Role of probiotics against mycotoxins and their deleterious effects. J Food Res, 2014; 4:10-21.

Voss K, Smith G, Haschek W. Fumonisins: toxicokinetics, mechanism of action and toxicity. Anim Feed Sci Technol, 2007; 137:299-325.

Voss KA, Chamberlain WJ, Bacon CW, Herbert RA, Walters DB, Norred WP. Subchronic feeding study of the mycotoxin fumonisin B1 in B6C3F1 mice and Fischer 344 rats. Fundam App Toxicol, 1995; 24:102-10.

Voss KA, Riley RT, Norred WP, Bacon CW, Meredith FI, Howard PC, Plattner RD, Collins TF, Hansen DK, Porter JK. An overview of rodent toxicities: liver and kidney effects of fumonisins and Fusarium moniliforme. Environ Health Perspect, 2001; 109:259-66.

WHO. Fumonisin B1, environmental health criteria 219. International Programme on Chemical Safety, World Health Organization, Geneva, 2000.

WHO. Evaluation of certain mycotoxins in food. WHO technical report series No. 906, Fifty-sixth Report of the Joint FAO/WHO Expert Committee on Food Additives, World Health Organization, Geneva, 2002.

Williams JH, Phillips TD, Jolly PE, Stiles JK, Jolly CM, Aggarwal D. Human aflatoxicosis in developing countries: a review of toxicology, exposure, potential health consequences, and interventions. Am J Clin Nutr, 2004; 80:1106-22.

Wu F, Munkvold GP. Mycotoxins in ethanol co-products: modeling economic impacts on the livestock industry and management strategies. J Agric Food Chem, 2008; 56:3900-11.
Yang YS, Ahn TH, Lee JC, Moon CJ, Kim SH, Jun W, Park SC, Kim HC, Kim JC. Protective effects of Pycnogenol on carbon tetrachlorideinduced hepatotoxicity in Sprague-Dawley rats. Food Chem Toxicol, 2008, 46:380-7.

Yin YN, Yan LY, Jiang JH, Ma ZH. Biological control of aflatoxin contamination of crops. J Zhejiang Univ Sci B, 2008; 9:787-92.

Zhang M, Fan X, Fang B, Zhu C, Zhu J, Ren F. Effects of Lactobacillus salivarius Ren on cancer prevention and intestinal microbiota in 1,2-dimethylhydrazine-induced rat model. J Microbiol, 2015; 53:398-405.

Zhang Y, Caupert J. A survey of mycotoxins in US distiller's dried grains with solubles from 2009 to 2011. J Agric Food Chem, 2012; 60:539-43.

Zoghi A, Khosravi-Darani K, Sohrabvandi S. Surface binding of toxins and heavy metals by probiotics. Mini Rev Med Chem, 2014; $14: 84-98$

How to cite this article:

Khalil AA, Gabal AA, Abdellatef AA, Zahran NM, Deraz SF. A natural approach to control induced fumonisin B1histopathological nephrotoxic and hepatotoxic changes in rats. J Appl Pharm Sci, 2019; 9(S1):017-029. 